\title{
C1GALT1C1 wt Allele
}

National Cancer Institute

\section{Source}

National Cancer Institute. C1GALT1C1 wt Allele. NCI Thesaurus. Code C112158.

Human C1GALT 1C1 wild-type allele is located in the vicinity of Xq24 and is approximately $4 \mathrm{~kb}$ in length. This allele, which encodes C1GALT1-specific chaperone 1 protein, plays a chaperone role in mucin-type O-glycan metabolism. Mutations in this gene are associated with somatic Tn polyagg lutination syndrome. 